\title{
Seismic Velocity Structures beneath the Guntur Volcano Complex, West Java, Derived from Simultaneous Tomographic Inversion and Hypocenter Relocation
}

\author{
Andri Dian Nugraha ${ }^{1}$, Sri Widiyantoro ${ }^{1}$, Awan Gunawan ${ }^{2} \&$ Gede Suantika ${ }^{3}$ \\ ${ }^{1}$ Global Geophysical Group, Faculty of Mining and Petroleum Engineering, \\ Institut Teknologi Bandung, Jalan Ganesa No. 10, Bandung 40132, Indonesia \\ ${ }^{2}$ Graduate Program of Earth Science, Faculty of Earth Science and Technology, \\ Institut Teknologi Bandung, Jalan Ganesa No. 10, Bandung 40132, Indonesia \\ ${ }^{3}$ Center for Volcanology and Geological Hazard Mitigation (CVGHM), \\ Jalan Diponegoro No. 57, Bandung 40122, Indonesia \\ Email: nugraha@gf.itb.ac.id
}

\begin{abstract}
We conducted travel time tomographic inversion to image seismic velocity structures $(\mathrm{Vp}, \mathrm{Vs}$, and $\mathrm{Vp} / \mathrm{Vs}$ ratio) with simultaneous hypocenter adjustment beneath the Guntur volcano complex that is located in the Garut district, West Java province, Indonesia. The Guntur volcano is one of the active volcanoes in Indonesia, although large eruptions have not occurred for about 160 years. We used volcanic and tectonic earthquakes catalog data from seismic stations deployed by Centre for Volcanology and Geological Hazard Mitigation (CVGHM). For the tomographic inversion procedure, we set grid nodes with a horizontal spacing of $2 \times 2 \mathrm{~km}^{2}$ and an average vertical spacing of $2 \mathrm{~km}$. Our results show low Vp, low Vs, and high Vp/Vs ratio regions beneath the Guntur crater and the Gandapura caldera at depths of 6-8 km and 7-9 km, respectively. These features can be associated with amelt-filled pore rock structure. However, a low $\mathrm{Vp} / \mathrm{Vs}$ ratio and low velocities are exhibited beneath the Kamojang caldera at depths of 2-6 km that may be associated with rock with $\mathrm{H}_{2} \mathrm{O}$-filled pores with a high aspect ratio.
\end{abstract}

Keywords: Seismic tomography; Guntur volcano; Seismic structure; Melt-filled pore; West Java.

\section{$1 \quad$ Introduction}

Indonesia is located in a very active tectonic region that is influenced by four major tectonic plates, i.e. the Eurasian, Indo-Australian, Caroline (Western Pacific) and Philippine Sea plates. As a result, Indonesia has 128 active volcanoes and high seismicity activity along the subduction zones within the Indonesian archipelago (Figure 1). In this tomographic study, we chose the Guntur volcano complex that is located in Garut, West Java, to investigate physical properties beneath this active volcano. The complex of the Guntur volcano includes the summit, crater, and caldera [1]. The Guntur volcano

Received February $29^{\text {th }}, 2012,1^{\text {st }}$ Revision August $29^{\text {th }}, 2012,2^{\text {nd }}$ Revision October $15^{\text {th }}, 2012$, Accepted for publication November $28^{\text {th }}, 2012$.

Copyright @ 2013 Published by ITB Journal Publisher, ISSN: 2337-5760, DOI: 10.5614/j.math.fund.sci.2013.45.1.2 
complex has two calderas, i.e. (i) the older Kamojang caldera in the western part, a geothermal area where a power plant is running, and (ii) the younger Gandapura caldera in the eastern part (Figure 2). The last large eruption of the Guntur volcano occurred in 1847 , which produced a tholeiitic basaltic flow reaching the Cipanas village near Tarong, about $4 \mathrm{~km}$ southeast of the Guntur crater [2]. In order to prepare for volcano hazard mitigation, we conducted a tomographic inversion to enhance our understanding of the geological features and physical properties of the Guntur volcano complex.

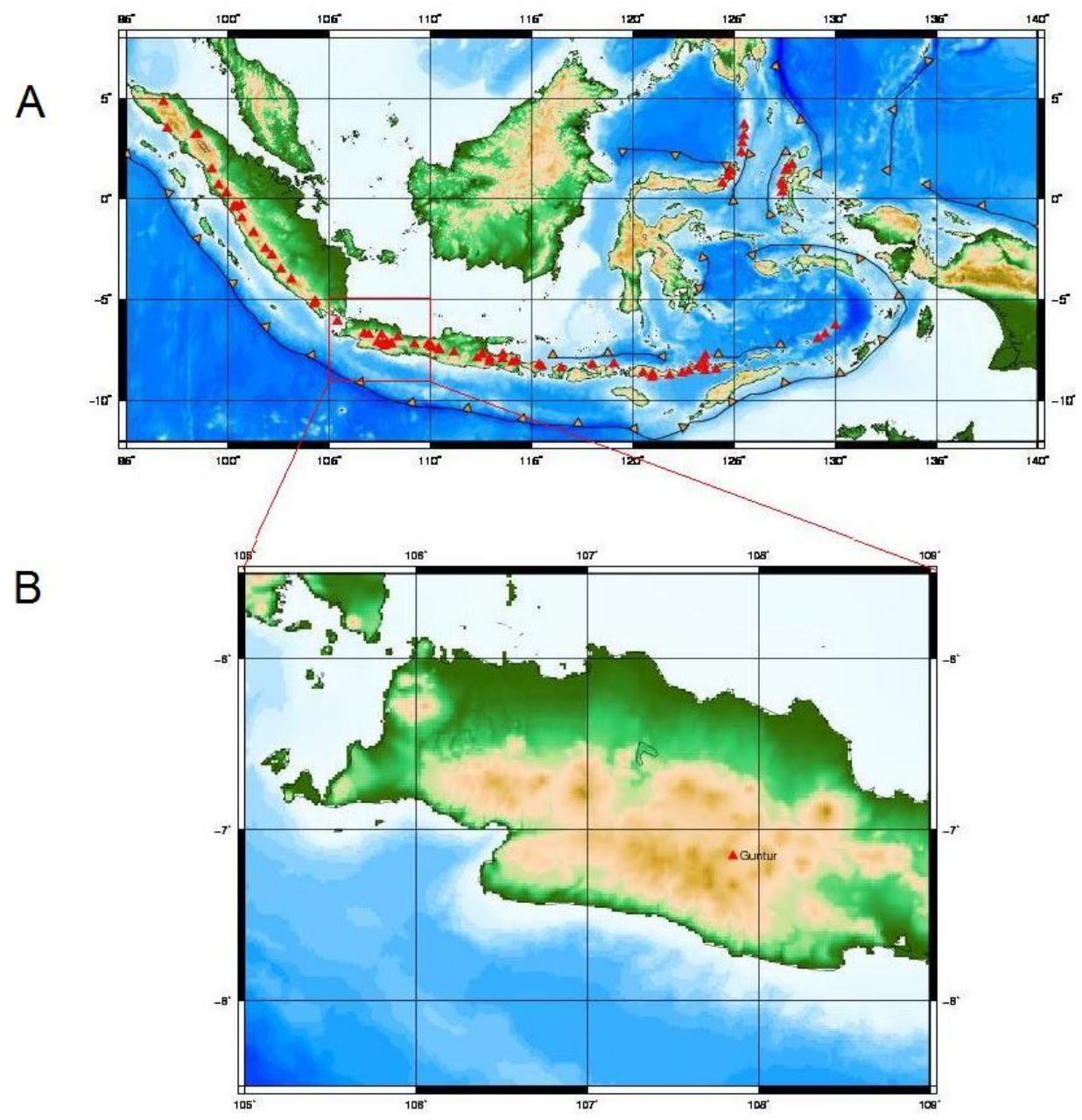

Figure 1 (A) Distribution of active volcanoes in Indonesia as indicated by the solid red triangles [3]. (B) The location of the Guntur volcano is in Garut, WestJava province. 


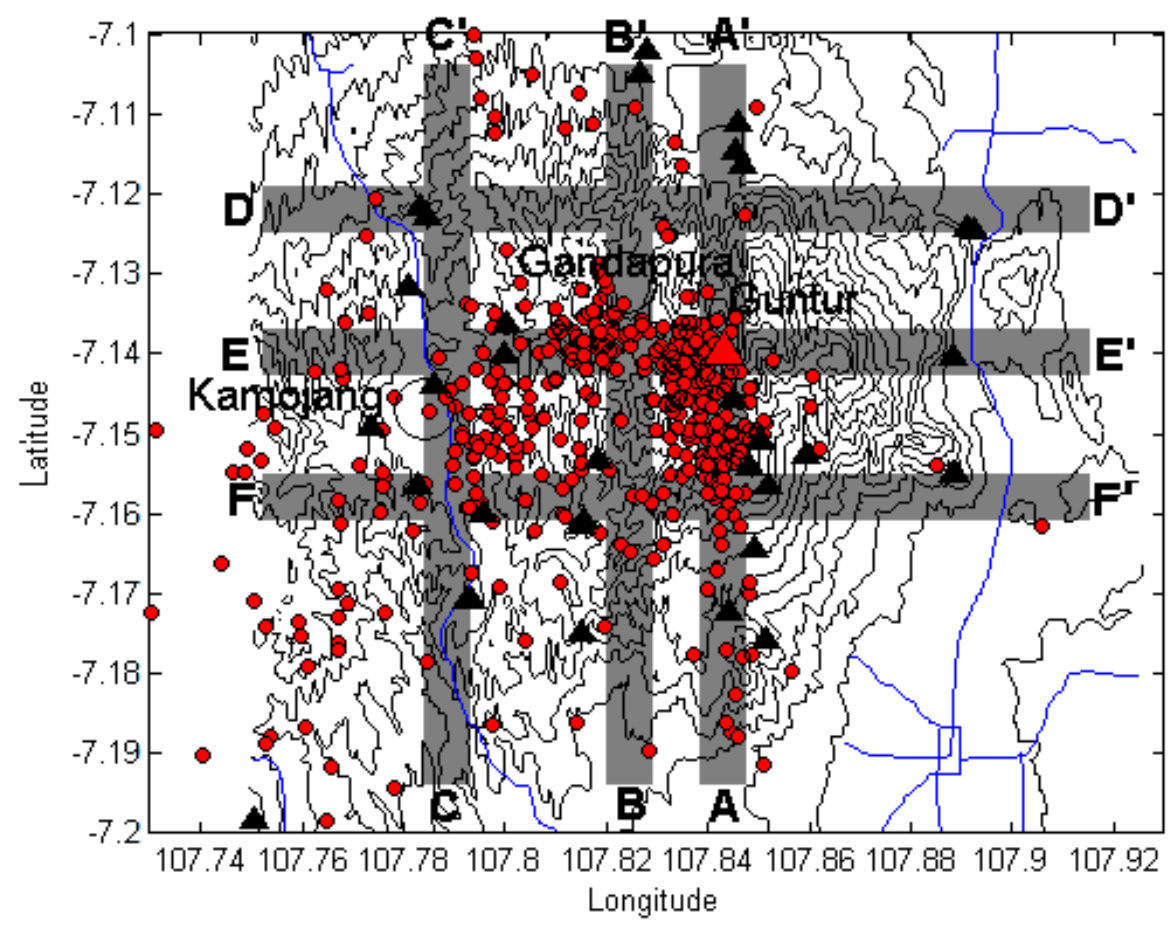

Figure 2 Topographic contour, relocated earthquake epicenters (red circles), and seismographic stations (black triangles). The red triangle depicts the location of the Guntur volcano. Thick, gray lines A-A', B-B', C-C', D-D', E-E', and F-F' depict the locations of the vertical sections presented in Figures 5 and 7.

\section{$2 \quad$ Data and Methods}

In this study, we used $\mathrm{P}$ and $\mathrm{S}$ arrival time data of volcanic and tectonic earthquakes provided by the CVGHM, inverted for three-dimensional velocity structures (Vp, Vs, and $\mathrm{Vp} / \mathrm{Vs}$ ) beneath the Guntur volcano complex. We applied the SIMUPLS12 method [4-8] to determine the 3-D Vp and Vp/Vs structures and simultaneously the hypocenter relocation. Predicted arrival times through the 3-D structure were calculated for ray paths using the pseudobending technique of Um and Thurber [9]. We used selected events provided by the CVGHM from 1995 to 2007. We did not use all earthquake events during that time period. Only those earthquake events were chosen that had a large number of picked arrival times (generally over 6 stations) and covered the region as well as possible. In total, 490 events with $4686 \mathrm{P}$ and $2343 \mathrm{~S}$ arrival times from 20 stations were used in this study for the tomographic inversion (Figure 3). The spatial resolution and setting of grid nodes for the $\mathrm{Vp}$ and $\mathrm{Vp} / \mathrm{Vs}$ inversion depended on the earthquake distribution, station distribution, 
and ray coverage. We used a horizontal grid spacing of $2 \times 2 \mathrm{~km}^{2}$ and a vertical spacing of $2 \mathrm{~km}$, which provide a fairly high spatial resolution and are relatively stable for the inversion.
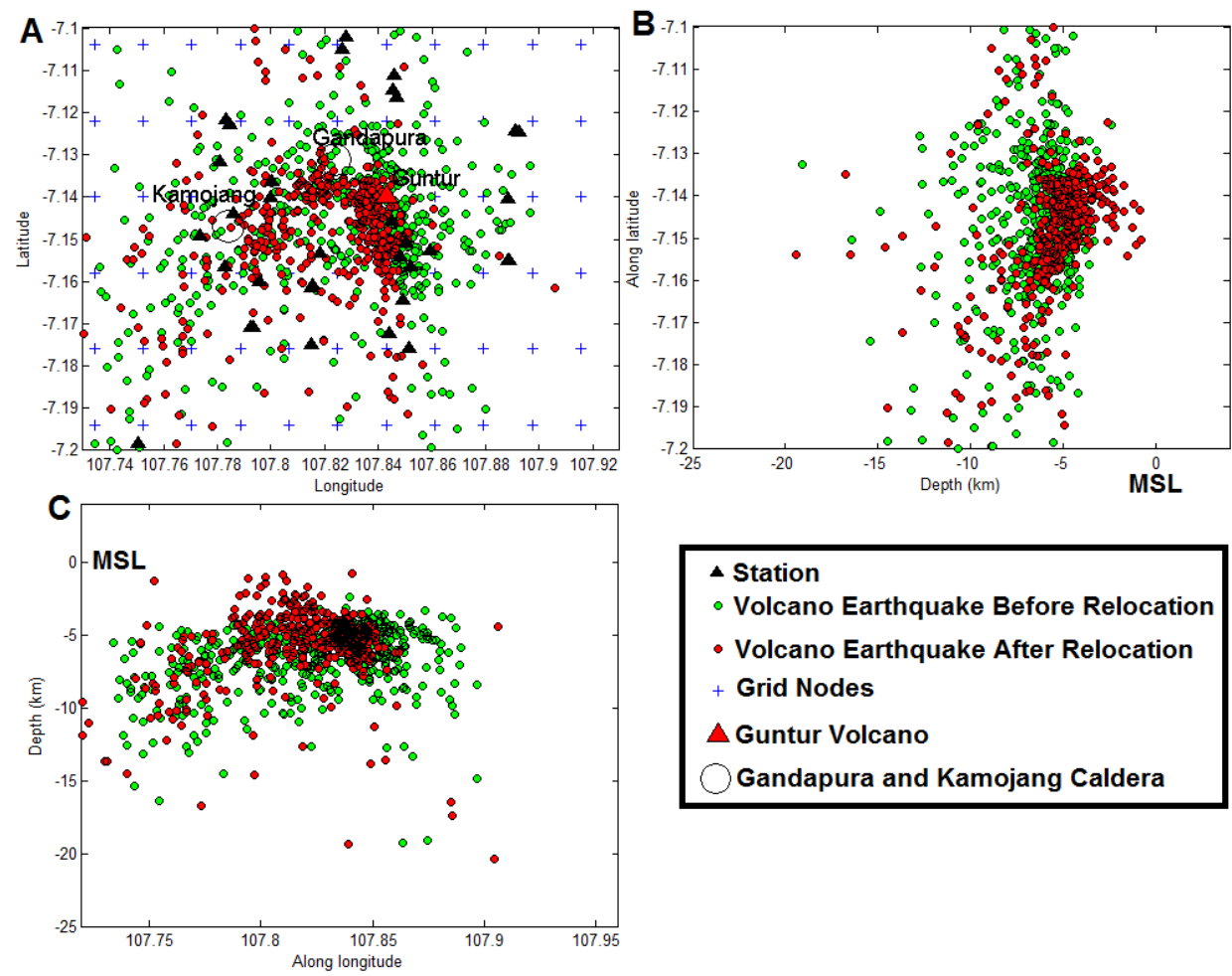

Station

- Volcano Earthquake Before Relocation

- Volcano Earthquake After Relocation

+ Grid Nodes

$\triangle$ Guntur Volcano

Gandapura and Kamojang Caldera

Figure 3 (A) Map of station distribution (black triangles), epicenter before relocation distribution (green circles), relocated epicenter distribution (red circles), grid nodes (blue plus), and the location of the Guntur volcano (red triangle) in the study area. (B) Associated hypocenter plot along the latitude. (C) Same as (B), but along the longitude.

During the tomographic inversion, we applied damping in order to stabilize the inversion processes. The purpose of damping is to a give a solution of the grid nodes without ray paths to bias relative to the initial velocity model, and to smoothen the model. The optimum damping values were selected from a tradeoff curve comparing data variance (misfit) with model variance, which showed a significant reduction in the data variance with a moderate increase in the solution variance (Figure 4). The optimal damping value varies with the amount and the distribution of the data, and the size and spacing of the grid model [8]. 

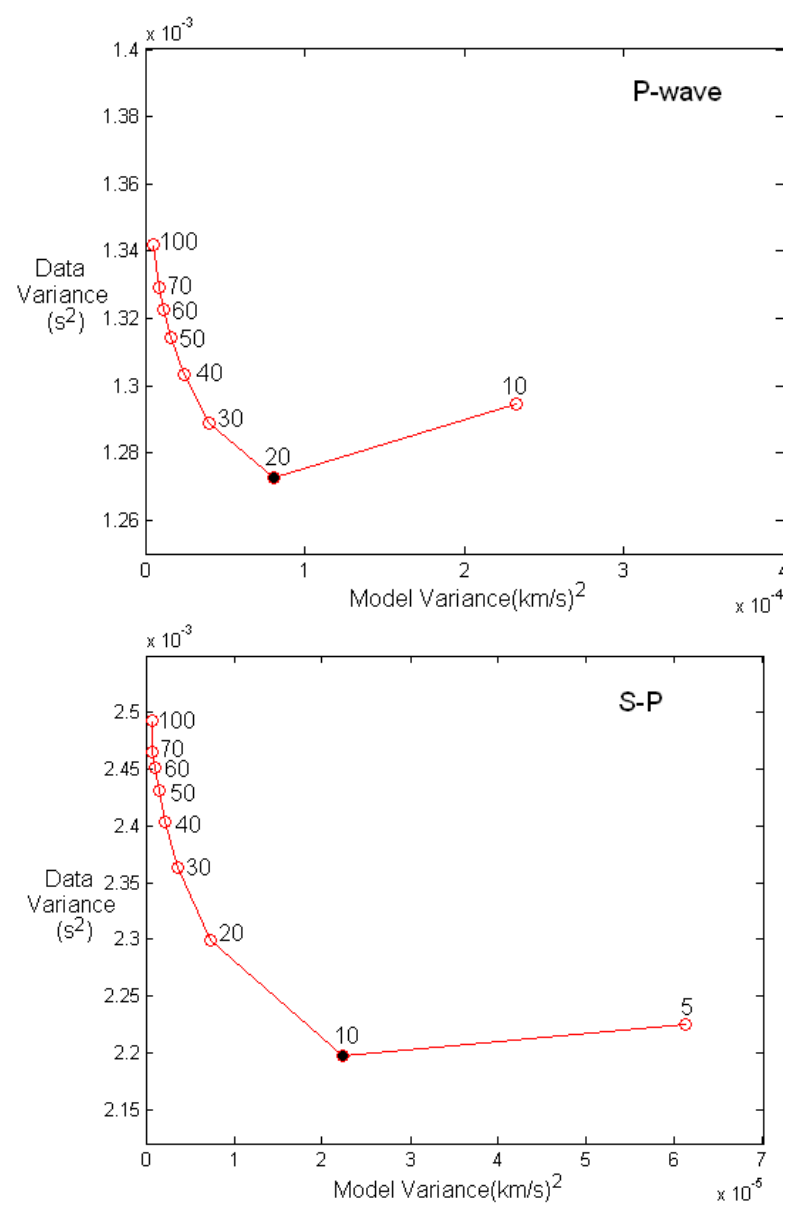

Figure 4 Curves indicating data variance versus model variance to determine the optimal damping parameter. The selected damping parameters are 20 and 10 for $\mathrm{Vp}$ and $\mathrm{Vp} / \mathrm{Vs}$, respectively, from one step inversion.

We started the tomographic inversion with an initial 1-D velocity from our previous work about the Guntur volcano complex [10]. We used an initial $\mathrm{Vp} / \mathrm{Vs}$ value of 1.80 [11]. The resolution of the tomographic model was evaluated using a checkerboard test, a diagonal resolution matrix, and a ray-hit count (Figures 5 and 6). The checkerboard test pattern was set with alternating fast and slow velocities at each grid point, with a contrast of $10 \%$ relative to the reference velocity model. A synthetic set of travel times was created for the checkerboard velocity pattern using the same ray paths as used in the real data inversion and then the synthetic data were inverted to explore how well the checkerboard pattern was recovered. The diagonal resolution element matrix 
[12] ranges from 0.0 to 1.0 , where 0.0 is unresolved and 1.0 is completely resolved.

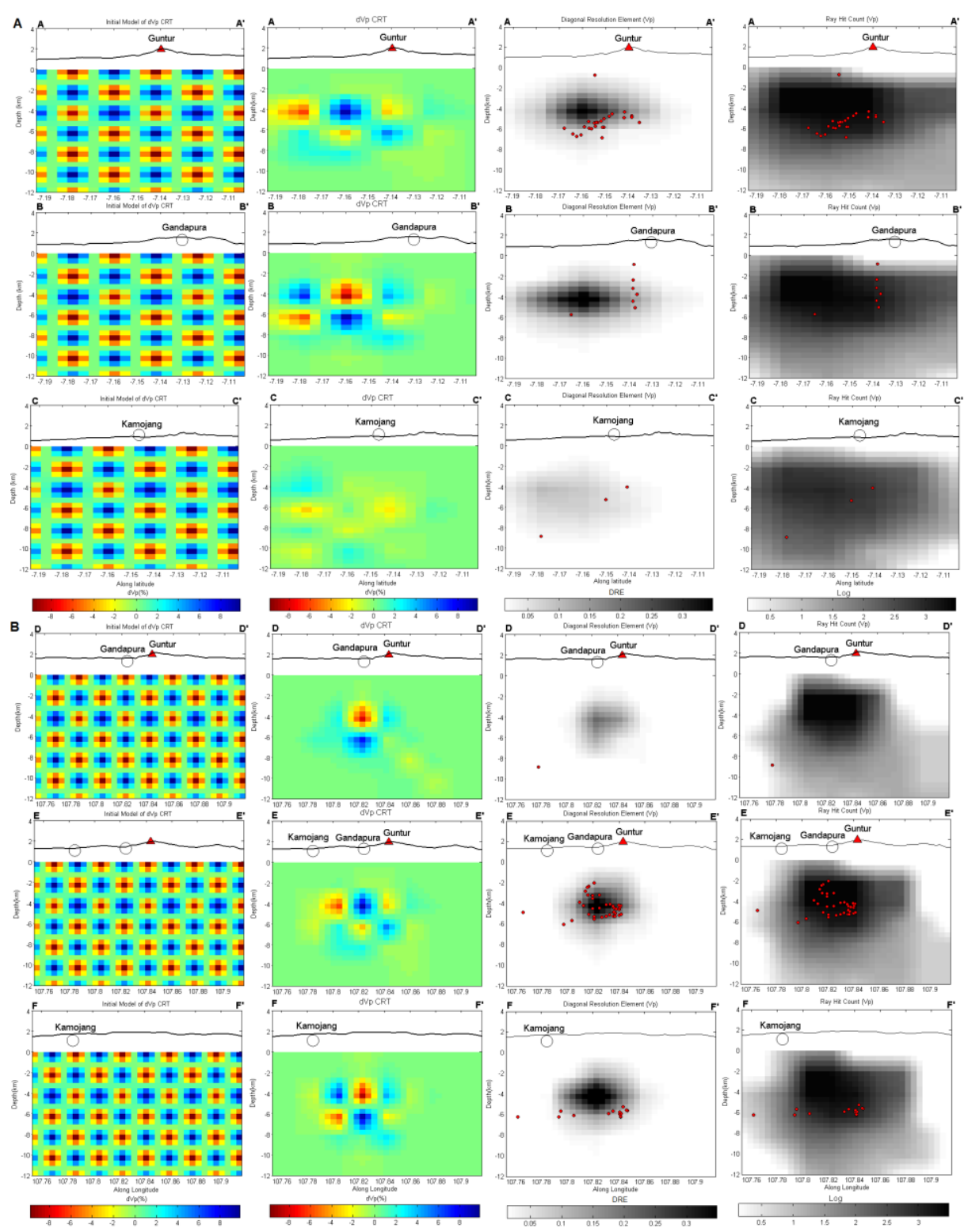

Figure 5 (A) Vertical sections across the initial checkerboard pattern and the recovered checkerboard pattern, diagonal resolution matrix, and ray hit count for P-wave data along AA', BB' and CC'. (B) As in (A), but for DD', EE' and FF'. 


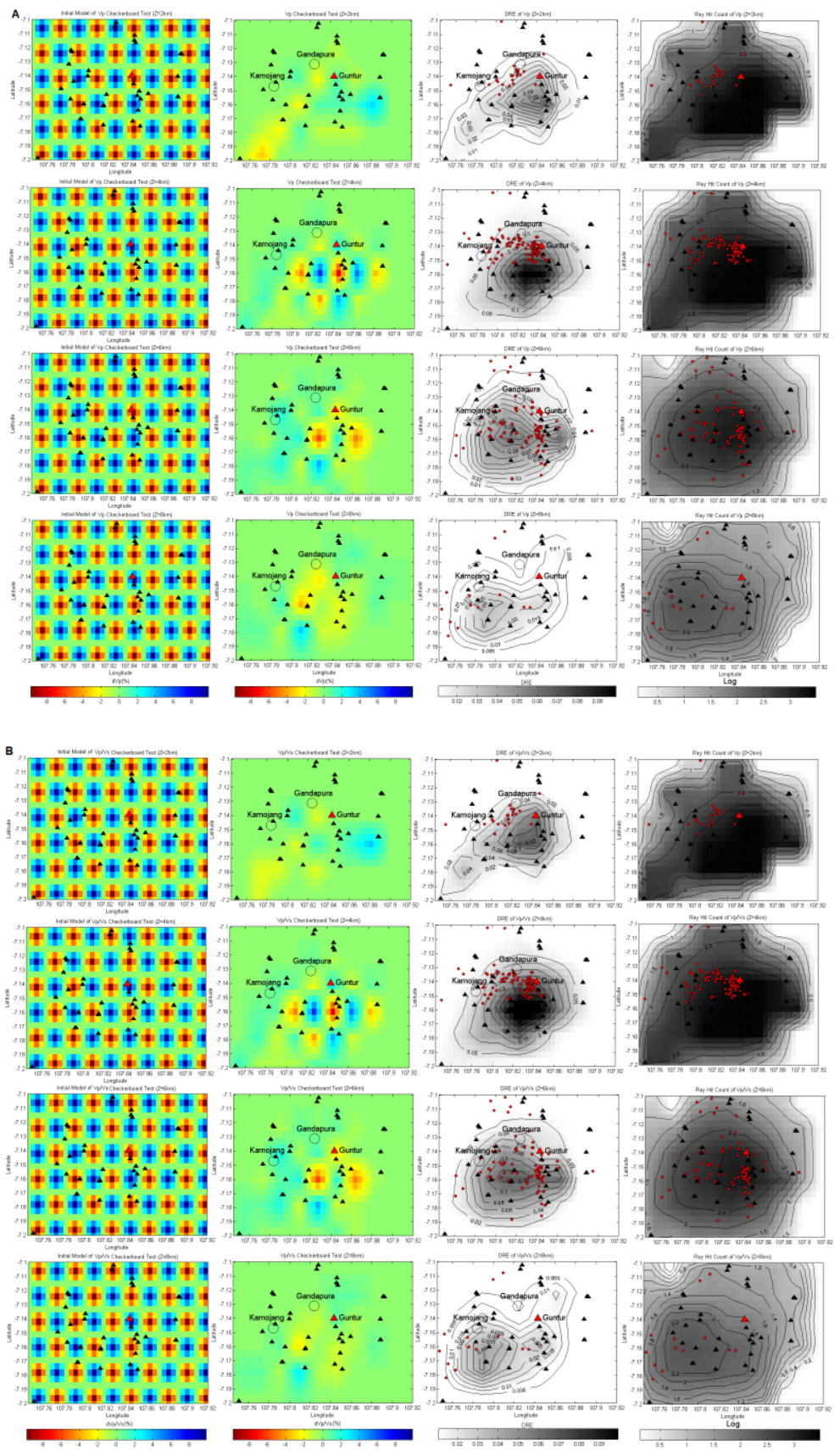

Figure 6 Horizontal sections of the initial checkerboard pattern and the recovered checkerboard pattern, diagonal resolution matrix, and ray hit count for $\mathrm{Vp}$ at depths of 4, 6, and $8 \mathrm{~km}$. (B) As in (A), but for $\mathrm{Vp} / \mathrm{Vs}$. 


\section{Tomographic Inversion Results}

Figure 5 shows vertical cross sections (AA', BB', CC', DD', EE', and FF') of
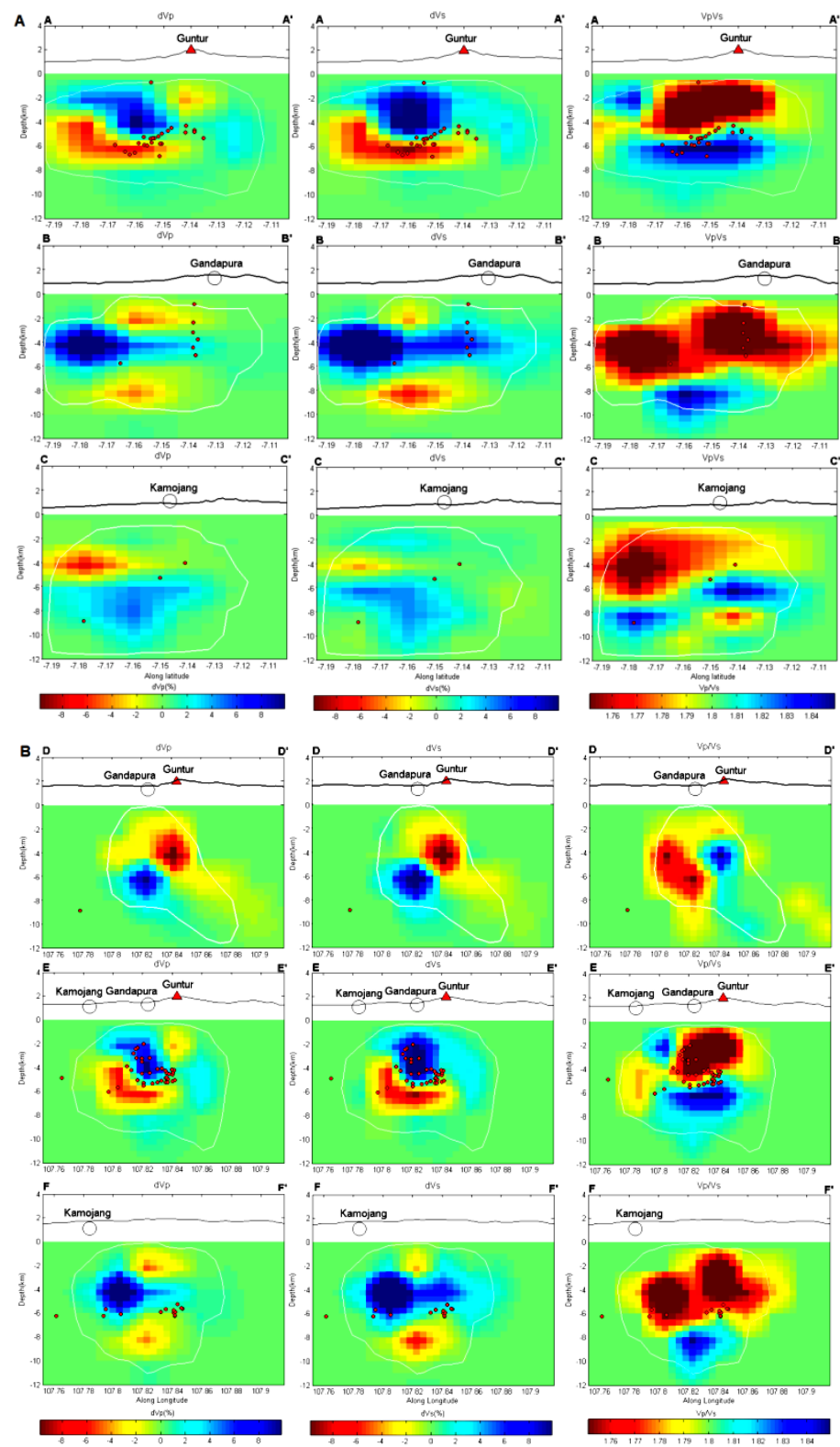

Figure 7 (A) Profiles of the P-wave velocity perturbations (dVp), S-wave velocity perturbations ( $\mathrm{dVs}$ ), and $\mathrm{Vp} / \mathrm{Vs}$ for $\mathrm{AA}^{\prime}, \mathrm{BB}^{\prime}$ and $\mathrm{CC}^{\prime}$. (B) same as $(\mathrm{A})$, but for DD', EE' and FF'. 

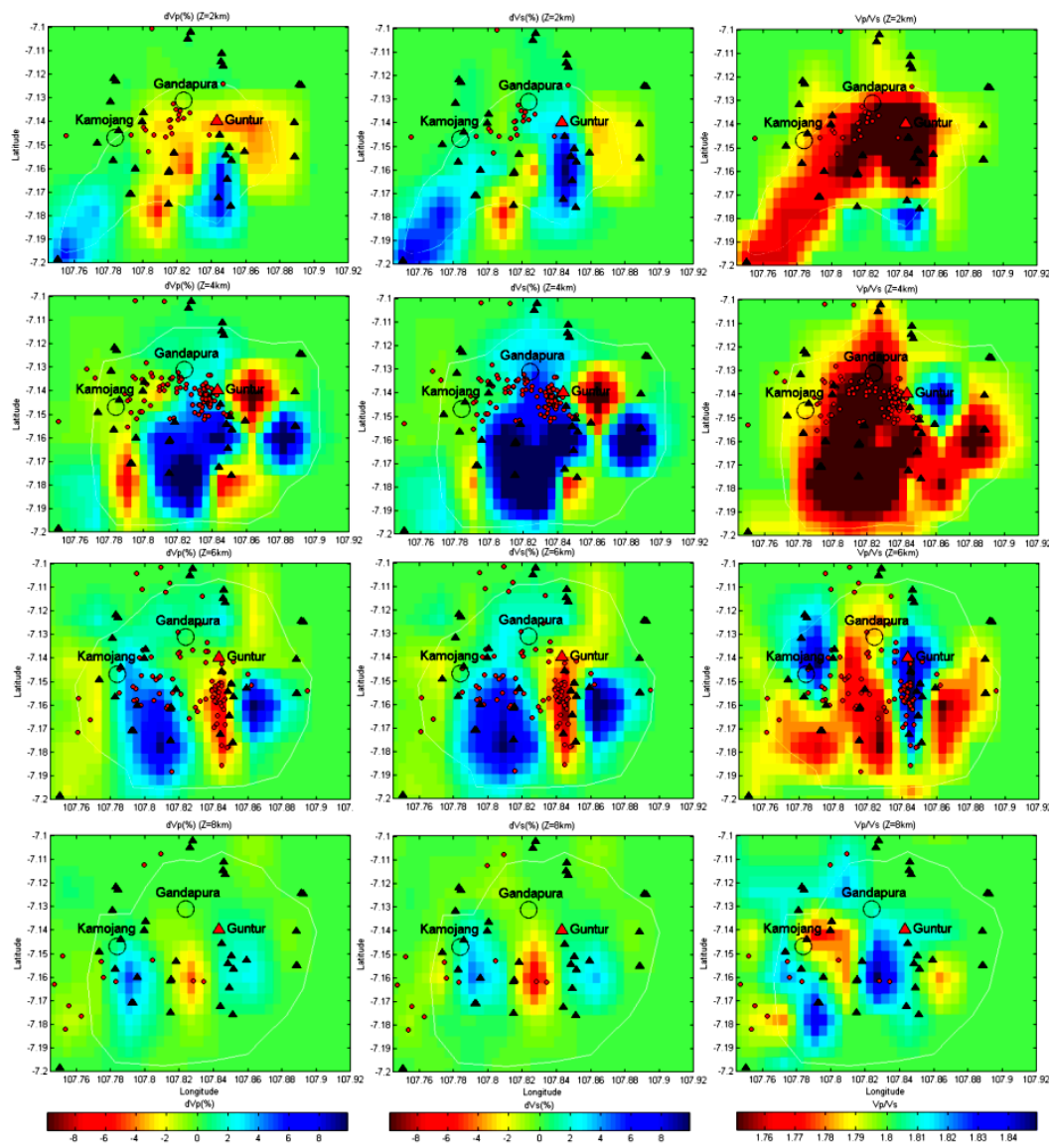

Figure 8 Horizontal map views of the P-wave velocity perturbations (dVp), left panel; S-wave velocity perturbations $(\mathrm{dVs})$, middle panel; and $\mathrm{Vp} / \mathrm{Vs}$, right panel, at depths of 4,6 , and $8 \mathrm{~km}$, respectively, from the Guntur summit.

the recovered checkerboard test along with the diagonal resolution matrix, and the ray hit count. Figure 6 shows horizontal map views of the recovered checkerboard pattern, the diagonal resolution matrix, and the ray hit count at a depth of $0 \mathrm{~km}$ (which is associated with the mean sea level - MSL), $2 \mathrm{~km}, 4 \mathrm{~km}$, $6 \mathrm{~km}$, and $8 \mathrm{~km}$. There is a good resolution beneath the Guntur crater, the Gandpura caldera, and the eastern part of Kamojang at depths of 4 to $10 \mathrm{~km}$. These areas are related to a high diagonal resolution matrix and high ray hit count values.

The results of the tomographic inversion for the vertical and horizontal sections through the Guntur complex are shown in Figures 7 and 8, respectively. Vp and Vs tomograms are shown as percentage differences from the initial 1-D model 
and $\mathrm{Vp} / \mathrm{Vs}$ were plotted using the absolute values. The obtained relocated hypocenters became more focused beneath the Guntur crater and the Gandapura caldera as shown in Figure 3.

For profiles beneath the Guntur crater (AA' and EE') in Figure 7, low velocity and high $\mathrm{Vp} / \mathrm{Vs}$ ratio anomalies were detected at depths of 6 to $8 \mathrm{~km}$. Profiles beneath the Gandapura caldera (BB' and EE') in Figure 7 show similar features of the low velocity and high $\mathrm{Vp} / \mathrm{Vs}$ ratio values at depths of 7 to $9 \mathrm{~km}$. Opposite features of anomalies of the low $\mathrm{Vp} / \mathrm{Vs}$ values and low $\mathrm{P}$ - and $\mathrm{S}$-velocities were observed beneath the Kamojang caldera at depths of 2 to $6 \mathrm{~km}$ (CC' in Figure $7)$.

For the horizontal map views shown in Figure 8, small areas of low velocity anomalies and high $\mathrm{Vp} / \mathrm{Vs}$ ratio values were observed $\left(107.86^{\circ}\right.$ and $-7.14^{\circ}$ coordinate) in the eastern part of the Guntur crater at a depth of $6 \mathrm{~km}$, and these anomalies also appear at a depth of $8 \mathrm{~km}$ beneath the southern part of the Guntur volcano. In the northern part of the Kamojang caldera, low velocity anomalies and high $\mathrm{Vp} / \mathrm{Vs}$ ratio values were observed at a depth of $8 \mathrm{~km}$.

\section{Discussion}

The tomographic inversion results show low velocity anomalies and high $\mathrm{Vp} / \mathrm{Vs}$ values beneath the Guntur summit and the Gandapura caldera at a depth of 6 to $8 \mathrm{~km}$, and 7 to $9 \mathrm{~km}$, respectively. These features are very interesting for active volcanic areas. Previous studies concluded that the existence of melt-filled pores and/or $\mathrm{H}_{2} \mathrm{O}$-filled pores apparently lowers seismic velocity and increases the Poisson's ratio $[13,14]$. Hence, according to our interpretation of the low velocity and high $\mathrm{Vp} / \mathrm{Vs}$ ratio anomalies beneath the Guntur summit and the Gandapura caldera, they may be associated with the melt-filled pores of the rock. The interpreted melt-filled pores of the rock beneath the Guntur summit may be related to a weak zone or a heat source and may trigger seismic activity beneath the active volcano. In the Kamojang region, a geothermal power plant has been operated for years. The anomaly beneath the Kamojang caldera exhibits low velocity and $\mathrm{Vp} / \mathrm{Vs}$ values. In previous studies, these phenomena were related to the existence of $\mathrm{H}_{2} \mathrm{O}$-filled pores with a large aspect ratio [e.g. $11]$.

\section{$5 \quad$ Concluding Remarks}

We have conducted simultaneous inversion for velocity structures and hypocenter adjustment. Our results show anomalies of low P-and S-velocity and a high Vp/Vs ratio beneath the Guntur summit and the Gandapura caldera that are interpreted to be related to melt-filled pores in the rock [cf. 13,14]. This 
interpretation is in good agreement with a recent study on the seismic attenuation tomography of Mt. Guntur by Priyono, et al. [15]. They concluded that the high seismic attenuation beneath the Guntur volcano system may be interpreted as a hot volcanic material zone or rock with melt-filled pores. These geological features are of importance to have a detailed understanding of the physical characteristics for volcano hazard mitigation.

\section{Acknowledgments}

We gratefully acknowledge the CVGHM for providing the earthquake data catalog used in this study. Thanks also go to the reviewers for their constructive comments. This work was supported by a research grant (Riset Peningkatan Kapasitas) from ITB, 2010 and a research grant from the Graduate Research on Earthquake and Active Tectonics (GREAT), ITB, 2011.

\section{References}

[1] Matahelemual, J., Gunung Guntur, Berita Berkala Vulkanologi Edisi Khusus, Direktorat Vulkanologi Bandung (in Indonesian), 1989.

[2] Kusumadinata, K., Data Dasar Gunungapi Indonesia, Direktorat Vulkanologi Bandung (in Indonesian), 1979.

[3] Kusumadinata, K., Hadian, R., Hamidi, S. \& Reksowirogo, L.G., Catalogue of References on Indonesian Volcanoes with Eruptions in Historical Time, Direktorat Vulkanologi, Direktorat Jenderal Pertambangan Umum, Departemen Pertambangan dan Energi, Republik Indonesia (in Indonesian), 1979.

[4] Eberhart-Phillips, D., Local Earthquake Tomography Velocities and Vp/Vs Theory, in Seismic Tomography: Theory and Practice, pp. 563583, H.M. Iyer \& K. Hirahara (Eds), CRC Press, Boca Raton, Fla, 1993.

[5] Evan, J.R., Eberhart-Phillips, D. \& Thurber, C.H., User's Manual for SIMULPS12 for Imaging Vp and Vp/Vs: Derivative of The "Thurber" Tomographic Inversion SIMUL3 for Local Earthquakes and Explosions, U.S. Geol. Surv. Open File Rep., pp. 94-431, 1994.

[6] Thurber, C.H., Earthquake Locations and Three-Dimensional Crustal Structure in The Coyota Lake Area, Central California, J. Geophys. Res., 88, pp. 8226-8236, 1983.

[7] Thurber, C.H., Local Earthquake Tomography Velocities and Vp/Vs Theory, in Seismic Tomography: Theory and Practice, pp. 563-583, H.M. Iyer \& K. Hirahara (Eds), CRC Press, Boca Raton, Fla, 1993.

[8] Nugraha, A.D. \& Mori, J., Three-Dimensional Velocity Structure in The Bungo Channel and Shikoku Area, Japan, and Its Relationship to LowFrequency Earthquakes, Geophys. Res. Lett., 33, L24307. doi: 10.1029/2006GL028479, 2006. 
[9] Um, J. \& Thurber, C.H., A Fast Algorithm for Two-Point Seismic Ray Tracing, Bull. Seismol. Soc. Am., 77, pp. 972-986, 1987.

[10] Nugraha, A.D., Suantika, G. \& Widiyantoro, S., Relocation of Earthquake Hypocenter at Mt. Guntur Area Using Three Dimensional Velocity Model, Jurnal Geofisika Indonesia, I, pp.1-6. (in Indonesian with abstract in English), 2006.

[11] Priyono, A., Suantika, G., Widiyantoro, S., Priadi, B.\& Surono, Three dimensional P-and S-wave Velocity Structures of Mt. Guntur, West-Java, Indonesia, from Seismic Tomography, International Journal of Tomography \& Statistic, 16(W11), pp. 1-11, 2011.

[12] Menke, W., Geophysical Data Analysis: Discrete Inverse Theory, Univ. Calif. San Diego, 1989.

[13] Nakajima, J., Hasegawa, A., Horiuchi, S., Yoshimoto, K., Yoshida, T. \& Umino, N., Crustal Heterogeneity Around The Nagamachi-Rifu Fault, Northeastern Japan, as Inferred from Travel-Time Tomography, Earth Planets Space, 58, pp. 843-853, 2006.

[14] Takei, Y., Effect of Pore Geometry on Vp/Vs: from Equilibrium Geometry to Crack, J. Geophys. Res., 107(B2), 2043. doi:10.1029/2001JB000522, 2002.

[15] Priyono, A., Suantika, G., Widiyantoro, S. \& Nugraha, A.D., ThreeDimensional Seismic Attenuation Structure of Mt. Guntur, West Java, Indonesia, International Journal of Tomography and Statistics, 17(S11), pp. 17-28, 2011. 